\title{
Competitive employer positioning through career path analysis: the case of the Swiss nursing sector
}

\author{
Remo Aeschbacher ${ }^{1 *}$ (iD and Véronique Addor ${ }^{2}$
}

\begin{abstract}
Background: The global shortage of nurses has caused strategic employer positioning and strengthened employer branding to become progressively relevant addressing the increased competition in the recruitment of nurses. This study provides competition-oriented strengths-and-weaknesses profiles for nurse attraction and attrition for the major types of healthcare institutions to advise on competitive employer positioning.

Methods: We applied bivariate weighted logistic regressions with cluster-adjusted standard errors to evaluate 4844 employer changes of 3011 nurses participating in the nurses at work study, whereby the reasons to quit (RQs) acted as both predictors of the former and the follow-up type of employer. For each employer type, we introduce a coordination system allocating each workplace criterion along its push and implicit pull characteristics, given through the specific odds ratios, to derive different strategic implications for an organisation's competitive nurse recruitment.
\end{abstract}

Results: Depending on the employer type, workplace criteria were variously acting as push or pull factors in nurses' career decisions.

Conclusions: Nurses' career choices are affected by experienced and presumed workplace characteristics associated with specific employer types. Becoming aware of these associations and experiences, employers should leverage workplace criteria with relatively strong pull or/and weak push characteristics by intensified communication measurements and criteria with relatively weak pull or/and strong push characteristics should be enhanced to a competitive level.

Keywords: Comparative study, Employer positioning, Hospitals, Non-profit organisations, Nursing, Nurse, Home-care, Types of institutions, Turnover, Working conditions

\section{Background}

Increased demand for care and problems in nursing supply, resulting from several factors including generational imbalances, technological advances, changes in the nursing job requirements and difficult working conditions (WCS), have led to a shortage of care professionals [1], which, in turn, facilitated voluntary turnover through

\footnotetext{
*Correspondence: remo.aeschbacher@gmx.ch

${ }^{1}$ University of Fribourg (CH), Bd de Pérolles 90, 1700 Freiburg, Switzerland

Full list of author information is available at the end of the article
}

ease of movement and compelled nurses to react more sensibly to poor WCS. Consequently, the competition to recruit nurses has increased worldwide, including in Switzerland [2-4]. Therefore, strategic positioning and strengthening employer branding is key.

However, data on which employer positioning in the health sector is based are limited to either specific comparative research on WCS aimed at hypothesis testing and therefore too narrow to apply on a holistic employer branding or firm-specific surveys and "best employer" studies, which are not generalisable. original author(s) and the source, provide a link to the Creative Commons licence, and indicate if changes were made. The images or other third party material in this article are included in the article's Creative Commons licence, unless indicated otherwise in a credit line to the material. If material is not included in the article's Creative Commons licence and your intended use is not permitted by statutory regulation or exceeds the permitted use, you will need to obtain permission directly from the copyright holder. To view a copy of this licence, visit http://creativecommons.org/licenses/by/4.0/. The Creative Commons Public Domain Dedication waiver (http://creativeco mmons.org/publicdomain/zero/1.0/) applies to the data made available in this article, unless otherwise stated in a credit line to the data. 


\section{Study aim}

Based on the theoretical and empirical groundwork of WCS across healthcare institutions, this study provides generic strengths-and-weaknesses profiles for major types of healthcare employers using a holistic inferential statistical approach.

Following secondary analyses of career statements originating from the nurses at work study [5], voluntary employer changes of nurses were assessed by first linking the various RQs to different types of left employers and, second, to use these RQs to predict the likelihood of different employer types being the follow-up employer. Thereof, we created the competitive strengths-and-weaknesses profiles for the largest types of nurses' employers in terms of attraction (pull factors) and attrition (push factors) of nurses. Irrespective of queries on firm-specific branding and business strategy, practical strategic implications for each profile are derived.

Besides practical conclusions, the study advances the academic debate on institution-specific effects in the health sector by adding a causal perspective on the competing relationship between the left and subsequent employer in voluntary turnover. Furthermore, by theorising and measuring the effect of organisational context on turnover, we address a research gap in turnover research in the nursing literature [6].

\section{Theoretical perspective on workplace differences between healthcare employers}

Studies that explain nurse turnover have applied conceptual models and theories that consider a wide range of variables involved at different stages leading up to voluntary turnover [6]. However, although studies in the field of general management have conceptualised voluntary turnover across the individual, workgroup and organisational analysis levels, researchers in the nursing field have mainly focused on studying turnover at the individual analysis level [6, 7]. Therefore, research has suggested integrating more theory from general management literature and other fields to build more integrated and powerful conceptual models studying nurse turnover $[6,7]$. Thus, our conceptual and theoretical framework relates to various variables, discussing individual RQs depending on the type of employer that varies in size, activity field and ownership at the organisational and macroeconomic levels. In reference to an integrated conceptual turnover framework such as the Integrated Turnover Model proposed in previous research, the assessed RQs and organisational types are found at the first stage (related to the nature of the job) and the second stage (organisational context, person-environment context and job attitudes) $[6,7]$.
Our study aims at examining the variance in turnover reasons due to workplace differences across organisational types to advise on employer positioning in the labour market rather than explain voluntary turnover per se. Thus, we use theories that provide an explanatory foundation for the variance in turnover reasons, at an organisational and macroeconomic level.

Empirical studies of workplace differences across different healthcare employers often focus on one-dimensional comparisons such as for-profit versus non-profit hospitals or stationary versus ambulant practices and therefore lack a holistic theoretical framework to compare workplace and turnover variables across a wider spectrum of organisation types.

Supporting our aim to compare a greater range of institutions characterised across multiple dimensions, we consult a broader theoretical framework which respects the practical nature of the categorisation but examines underlying definitory variables.

Public hospitals, private for-profit hospitals, sociomedical institutions such as nursing homes (SOMEDs), home care services, private medical offices and general practitioners and non-profit organisations (NPOs) are the main types of employers for nurses in Switzerland. This categorisation is based on bundled variations in organisational size, activity type, and ownership and goal systems, which can therefore be regarded as mediators of institutional differences. Hence, a combined view on theories and concepts, as outlined in Table 1 [8], helps to comprehend potential differences in perceived workplace conditions across healthcare institutions.

\section{Nurses' WCS and turnover across different types of organisations}

Previous comparative research of WCS across various institutions can be presented well following the structure of the theoretical discussion. Studies comparing organisations of different sizes show that working with larger healthcare employers, such as hospitals, is associated with more work strain and burnout, less autonomy and participation, and more regulation and burnout [34-38].

Comparison studies of work settings across various activity types found that nurses working with challenging patients, typically in long-term care (i.e. SOMEDs), experience more stress and burnout $[39,40]$, but show more organisational commitment and higher professional identification [36]. Nurses working in outpatient or home care (i.e. home care services) in contrast to stationary care experience more autonomy, less regulation [36, 41], less work strain [39] and job satisfaction [36] and report higher meaning of work [42].

Research comparing workplaces with various types of ownership and goal systems found that nurses in the 
Table 1 Mediators of perceived differences in workplace variables across institutions [8]

\begin{tabular}{|c|c|c|}
\hline $\begin{array}{l}\text { Underlying mediators of } \\
\text { institutional differences }\end{array}$ & Description & Associated theories \\
\hline Organisational size & $\begin{array}{l}\text { Organisational size is a pivotal variable in classic organisa- } \\
\text { tional theory and considered a key mediator of differ- } \\
\text { ences in organisational structures, WCS and behaviour. } \\
\text { According to the Formal Theory of Differentiation in } \\
\text { Organisations and the Evolutionary Model of Organisa- } \\
\text { tion, size leads to the distinct characteristics of work, } \\
\text { for example, by promoting functional specialisation, } \\
\text { divided responsibility, wider control spans, standardisa- } \\
\text { tion, formalisation and less centralisation [9-11]. More } \\
\text { recent economic theories have described the effects } \\
\text { of organisational size on WCS, particularly the positive } \\
\text { effect on compensation, training, promotion opportuni- } \\
\text { ties, job security and the negative effect on participation, } \\
\text { meaningful work, worker's confidence, autonomy and job } \\
\text { satisfaction [12-21] }\end{array}$ & $\begin{array}{l}\text { e.g. Formal Theory of Differentiation in Organisations [9]; } \\
\text { Evolutionary Model of Organisation [10]; High-perfor- } \\
\text { mance work systems [13] }\end{array}$ \\
\hline Activity type & $\begin{array}{l}\text { Activity type refers to the type of treatment, patients and } \\
\text { locations a healthcare provider is associated with, which, } \\
\text { according to the self-determination theory and the } \\
\text { job characteristics theory, can impact work motivation, } \\
\text { exhaustion and overall job satisfaction by offering various } \\
\text { levels of personal-identity-fit, perceived impact on others, } \\
\text { meaning and interestingness, as well as autonomy and } \\
\text { feedback [24-24]. Moreover, with regard to the effect of } \\
\text { patient types, social interaction theories suggest that the } \\
\text { quality of nurse-patient relationships affects nurses' well- } \\
\text { being and work strain by positive and negative regulation } \\
\text { of emotions [25, 26]. Finally, context variables indirectly } \\
\text { impact WCS by being linked to activity type. For example, } \\
\text { in Switzerland, different billing systems for various treat- } \\
\text { ments affect nurses'WCS by promoting cost-savings [27, } \\
\text { 28] }\end{array}$ & $\begin{array}{l}\text { e.g. Self-determination theory }[22,25] \text {; Economisation at } \\
\text { hospitals }[27,28] \text {; Job characteristics theory [23], }\end{array}$ \\
\hline Ownership and goal system & $\begin{array}{l}\text { Ownership and goal systems refer to institutions being in } \\
\text { either private or public ownership and following for-profit } \\
\text { or non-profit objectives. As for-profit, non-profit and } \\
\text { public organisations typically act consistent with different } \\
\text { macroeconomic roles [29], they promote different work- } \\
\text { place characteristics and therefore offer different intrinsic } \\
\text { and extrinsic stimuli for workers' motivation. From the self- } \\
\text { determination theory perspective, promoting autonomy, } \\
\text { relatedness and competence increases workers' intrinsic } \\
\text { motivation [22] and job satisfaction [30, 31]. NPOs offer } \\
\text { more autonomy because of the relative absence of } \\
\text { competitive or legislative/regulatory pressure, compared } \\
\text { with for-profit or public organisations, while both public } \\
\text { organisations and NPOs can offer more relatedness at } \\
\text { work than their for-profit counterparts because of public } \\
\text { service motivation [32, 33] }\end{array}$ & $\begin{array}{l}\text { e.g. Three-Sector Economy [27], Public Service Motivation } \\
\text { [33], Self-determination theory [22] }\end{array}$ \\
\hline
\end{tabular}

private sector, rather than the public sector, experience less administrative workload [27], less violence, more recognition [35], higher commitment [43] and greater job satisfaction [44]. However, nurses at public hospitals are more likely to be satisfied with salary and experience more job stability and employee benefits [45]. Nurses working at NPOs report less burnout [46] while earning more [47] and reporting greater well-being [48]. Generally, employees at private medical offices experience more autonomy and job satisfaction [32, 49].
Finally, using the introduced typology of the main six employers of Swiss nurses-public hospitals, private hospitals, private medical offices, socio-medical institutions, non-profit organisations and home care servicesa recent comparative study shows that nurses working in private hospitals and public hospitals were less likely to experience autonomy and worktime flexibility than those working at smaller healthcare employers, whereas work at public hospitals, rather than at private hospitals, was associated with more stress, yet associated with more satisfaction with salary and advancement opportunities. 
Compared with other workplaces, SOMEDs were associated with more alienating WCS and lower job satisfaction, but with more participation and decision-making. In contrast, private medical offices were associated with a milder work environment and more social support than other institutions. Finally, working at NPOs and home care services was associated with higher degrees of autonomy, recognition, organisational commitment and job satisfaction [8].

Besides the assessment of WCS, nurse staffing and turnover were the focus of several studies, especially because they are linked to patient safety, health outcomes and mortality [52-54]. With lower overall job satisfaction, the tendency for turnover is greater [57-58]. More specifically, strong positive predictors of turnover or turnover intent in nursing are job stress, workload, emotional exhaustion and burnout [59-66]. Further factors significantly linked to turnover are satisfaction with salary, career opportunity and professional development [64, 65, 67], organisational commitment [58, 63, 68], team culture, peer networks and leadership [59, 63, 65, $67,69-72]$, job characteristics such as non-nursing tasks [66], meaningful work [57], job complexity [63], perceived patient safety, sex (i.e. being male) [66], autonomy, participation and recognition $[57,63,64]$.

Research on nurses' turnover by type of institution is scarce compared to studies of turnover reasons in general. However, even if not differentiating between different RQs, several studies compare turnover intention or actual turnover across different employer types and settings. Nursing staff in nursing homes and hospitals is found to consider leaving nursing more often than those in home care [36], staff in hospitals more often considers leaving nursing than in primary outpatient care and nursing homes [73] and nursing staff in private hospitals considers leaving nursing to a higher degree than those working in psychiatric hospitals [74]. Moreover, nurses in nursing homes report greater intention to leave than nurses working in private or public hospitals [75]. Nurses in geriatric care are more likely to quit their job [76]. Finally, smaller work units, outpatient units and day care settings are associated with lower staff turnover [72]. Thereby, nurses working in home care may have a lower turnover propensity because workers in low-wage home care perceive more meaning and dignity. After all, it is supposed that nurses enter home care after quitting an alienating job, within or outside the healthcare industry [42].

\section{Methods}

Data

We used data from the nurses at work study [5], a retrospective longitudinal cohort study of career paths of nurses who worked in Switzerland between 1970 and 2014. 15,301 nurses answered the online questionnaire between September 2014 and February 2015. The survey included questions about experienced WCS and RQs as well as it included a parallel section on simultaneous personal events, socio-demographic data and personality type.

\section{Sample}

To evaluate the pull and push characteristics of workplace criteria, we focused on voluntary staff turnover between the six main types of healthcare employers who employ roughly 90 per cent of all professional nurses, namely public hospitals, private hospitals, private medical offices, SOMEDs, NPOs and home care services [8]. After excluding movements within the same type of institution and movements from workplaces at which individuals worked less than one full day and/or had a tenure below one month, we analysed 4844 movements from 3011 nurses [see Additional file 1 for more details].

\section{Reasons to quit}

In the nurses at work study, respondents were asked to state why they left each of their former employers. The question 'For what reasons did you leave this job?' was only prompted if the turnover was voluntary, e.g. due to dissatisfaction with the job, due to a job offer or due to personal reasons. With the instruction 'Please state any reasons that led you to leave the position', the respondents were asked to select multiple RQs from a catalogue of 28 statements which contained items concerning the WCS as well as some items addressing reasons coming from outside of the organisation (e.g. job offer). Respondents could answer with yes or no or does not concern me in the case of a workplace could not be assessed in terms of this criterion. The catalogue of RQs concerning characteristics of the workplace or the tasks were, mostly, directly derived from validated variables addressing WCS [5].

\section{Statistical analysis \\ Principal component analysis}

To reduce the number of RQs and ease results' visualisation, we applied principal component analysis (PCA) based on a tetrachoric correlation matrix and obtained orthogonal (independent) factors via varimax rotation. The Kaiser-Meyer-Olkin measure of sampling adequacy indicated that PCA was appropriate. Thus, in the final analysis, we assessed overall 18 RQs (see Table 2).

\section{Regression analysis}

Research on turnover at the organisational level and addressing staff migration on macroeconomic level states 
Table 2 Measures of reasons to quit

\begin{tabular}{|c|c|c|}
\hline Latent construct name & Item name (binary scale: $0=$ no; $1=$ yes) & Statement \\
\hline Non-nursing tasks avoidance & Non-nursing tasks avoidance (RQ1) & $\begin{array}{l}\text { I had to do too many non-nursing tasks (for example, picking up the food } \\
\text { plateaus) }\end{array}$ \\
\hline Work hours & Work hours (RQ2) & My working hours were too inconvenient \\
\hline Care quality & Care quality (RQ3) & $\begin{array}{l}\text { I had the impression that the quality of the care and/or the patient safety } \\
\text { were insufficient }\end{array}$ \\
\hline \multirow[t]{3}{*}{ Exhaustion (KR-20 =.70) } & Stress (RQ4) & The work was too stressful, too much physical and/or mental stress \\
\hline & Professional exhaustion (RQ24) & I was in a state of professional exhaustion \\
\hline & Health problems (RQ25) & I had a health problem \\
\hline Violence & Violence (RQ5) & $\begin{array}{l}\text { There was increased verbal or physical violence from patients/relatives to } \\
\text { nurses }\end{array}$ \\
\hline \multirow[t]{3}{*}{ Wish for change $(\mathrm{KR}-20=.50)$} & Interest in other profession (RQ6) & I was interested in another profession \\
\hline & Professional development wish (RQ7) & I wanted to professionally develop \\
\hline & Education wish (RQ27) & I wanted to do an education / a training \\
\hline Skill-use opportunity & Skill-use opportunity (RQ8) & I was not able to use my nursing education and specific skills \\
\hline \multirow[t]{2}{*}{ Self-actualisation (KR-20 = .67) } & Autonomy (RQ9) & I could hardly work independently \\
\hline & Participation (RQ10) & $\begin{array}{l}\text { I had very little opportunity to decide (about the patient care, the depart- } \\
\text { ment, the company) }\end{array}$ \\
\hline Mobbing & Mobbing (RQ11) & I was bullied at the workplace \\
\hline Interesting job offer & Interesting job offer (RQ12) & I got an interesting job offer \\
\hline \multirow[t]{2}{*}{ Advancement $(K R-20=.64)$} & Training opportunities (RQ13) & I could hardly benefit from further training opportunities \\
\hline & Career opportunities (RQ14) & I did not have enough career opportunities \\
\hline \multirow[t]{2}{*}{ Team $($ KR-20 =.79) } & Team mood (RQ15) & The team mood was bad \\
\hline & Team cooperation (RQ16) & The cooperation in the team was unsatisfying \\
\hline \multirow[t]{2}{*}{ Superiors $(K R-20=.78)$} & Superiors'support (RQ17) & I did not get enough support from my superiors \\
\hline & Recognition (RQ18) & My work has not been sufficiently recognised \\
\hline Organisational commitment & Organisational commitment (RQ19) & At that time, I had no sense of belonging to this organisation \\
\hline Professional identification & Professional identification (RQ20) & At that time, I was only slightly identified with the nursing profession \\
\hline \multirow[t]{2}{*}{ Work-life balance $(\mathrm{KR}-20=.67)$} & Work-life balance (RQ21) & I wanted more time for my private life (for example family, travel ...) \\
\hline & Taking care of children (RQ22) & I wanted to look after my children \\
\hline Moving to a new house & Moving to a new house (RQ23) & I moved houses \\
\hline Salary & Salary (RQ26) & The compensation and/or social benefits were unsatisfying \\
\hline
\end{tabular}

push-and-pull factors. Push factors refer to the factors leading to dissatisfaction at the workplace, which in turn leads to turnover. In contrast, the actual situation on the labour market or the available alternatives has been considered pull factors [77]. However, this study argues that a criterion leading to turnover from a specific employer can be considered an implicit pull factor from the followup employer's perspective [78]. Although this indirect measure of pull factors can be considered a limitationas the reasons to join employers were not surveyed-the approach benefits the interpretation of results. Implicit measurement of pull factors ensures the conceptual integrity when comparing the push-and-pull factors and informs about the competitive significance of the factor for a specific organisation type as it earlier led to turnover from another. With a direct assessment of pull factors associated with a subsequent employer, respondents would omit factors, especially unsatisfied hygiene factors associated with the former employer, that led to the employer change, in the first place.

Since we only looked at voluntary turnovers, the underlying axiom is that the follow-up employer is expected to perform better in the criterion that led to the withdrawal from the previous employer [79]. Thus, a criterion, on the one hand, can be either a significantly more frequent RQ (strong push argument) for nurses of a certain type of organisations, a significantly less frequent RQ (weak push argument), or an average frequent RQ (average push argument), compared to turnovers from other types of organisations. On the other hand, the criterion can in the same way be characterised as strong, weak, or average pull argument by estimating the likelihood of a certain type of employer being chosen after leaving the former employer because of this very criterion.

Figure 1 illustrates a coordination system along which push-and-pull characteristics of a criterion can be 


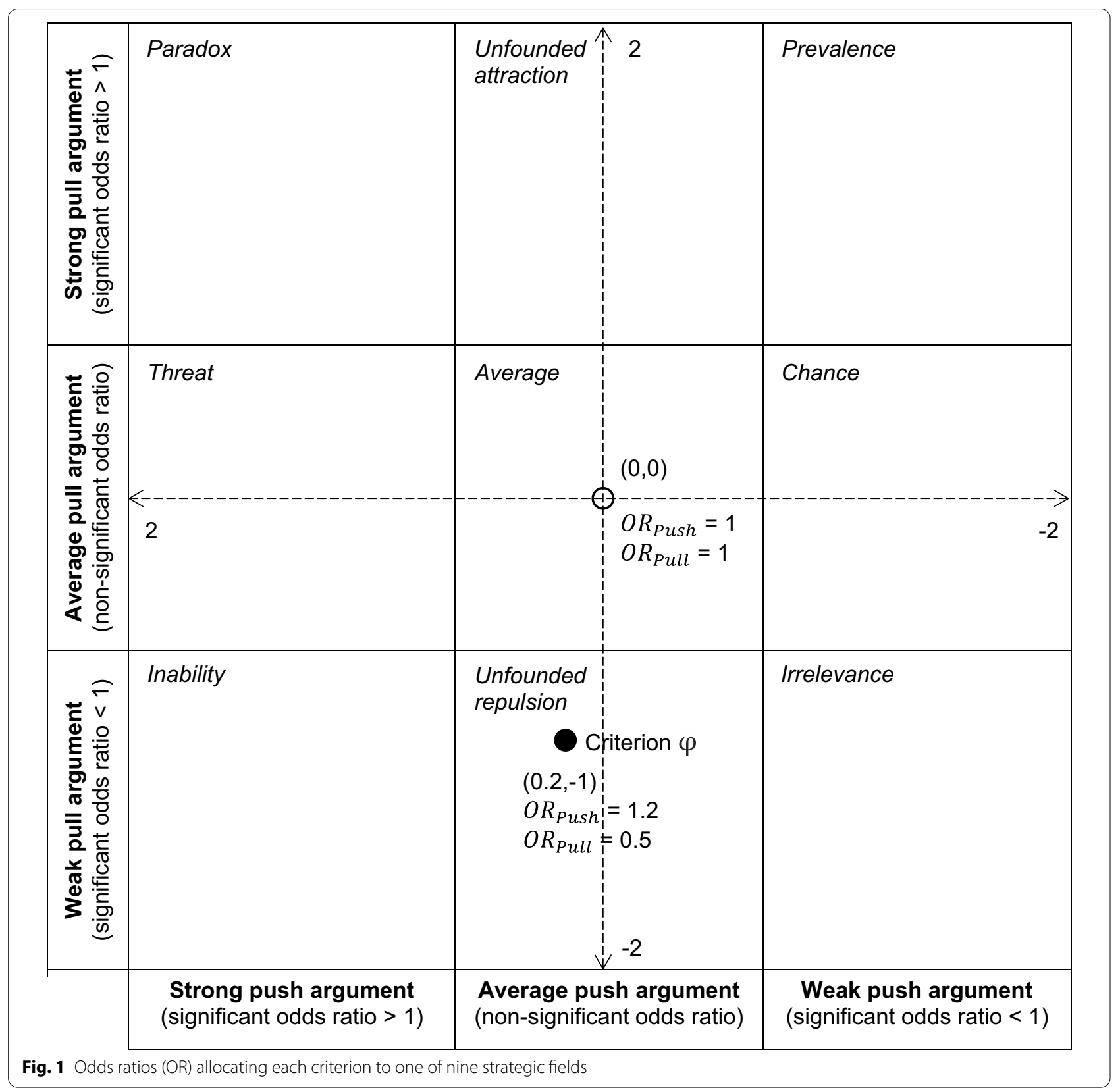

directly displayed allocating the specific criterion to one of nine strategic fields. The fields are named after what specific factors in these fields should be perceived as by managers. For each field, we suggest different generic employer reactions, which can be retrieved in detail from Additional file 2.

In our analysis, the location of the criteria for each type of organisation relied on the results of $2 \times 18$ bivariate weighted logistic regressions (with clusteradjusted standard errors), whereby the specific RQ first acted as predictor of the organisational type being the prior employer (defining the push characteristics), and second, acted as predictor of the specific organisational type being the follow-up employer (defining the implicit pull characteristics). In each of the two models, the specific type of organisation (as prior and followup employer, respectively) was coded as dependent dummy variable, 1 meaning that the specific type was left (push model) or chosen (pull model), 0 meaning that another type was left (push model) or chosen (pull model). Since, in the reference group (0), more frequently involved types of organisations also would 
have shaped the characteristics of the reference group more heavily, the cases were weighted so that each type of organisation affected the reference group of the dependent variable in an equal manner.

We employed odds ratios (ORs) indicating the degree to which the odds of leaving (ORs $\left.s_{\text {Push }}\right)$ or going to $\left(O R s_{\text {Pull }}\right)$ a specific type of organisation is increased $(O R>1)$ or decreased $(O R<1)$ when a nurse indicated a certain RQ. Thus, when regressing a certain type of former employer on a specific RQ was associated with a significant $O R$ above 1 , the RQ was considered as a strong push factor, relatively to its peculiarity with the turnovers from other types of former employers. When the RQ was associated with a significant $O R$ below 1 , it was considered as a weak push factor, relatively to its peculiarity with other types of former employers. The same principle applies to the type of follow-up employer we regressed on the RQ associated with the former type of employer, in this respect acting as pull factors. If there was no significant relative prevalence or infrequency of a turnover argument associated with the specific type of former or follow-up employer, it was considered as an average push or pull argument, respectively.

The exact coordinates of the criteria in the diagram indicating competitive strengths-and-weaknesses were determined by the odds ratios $(O R)$ as multipliers of the odds if they were equal to or greater than 1, or dividers $\left(\frac{1}{O R}\right)$ of the odds in the case $O R$ were below 1 . Starting from a neutral point in the centre of the diagram $(0,0)$, multiplier characteristics were displayed as $O R-1$, in the direction of the strong predicate, and dividers were displayed as $\left(\frac{-1}{O R}+1\right)$, in the direction of the weak predicate.

Thus, for a for criterion $\phi$ the $x$ coordinate was defined as follows:

\section{Discussion}

\section{Public hospitals}

Figure 2 indicates that nurses were more likely to work for a public hospital as a follow-up employer (strong pull arguments) when they quit their jobs because of low skilluse and advancement opportunities, when they wanted a professional change, when they were dissatisfied with salary and/or when they quit because of too many nonnursing tasks. In turn, these reasons were, as well, less indicated as RQ by nurses who left public hospitals (weak push arguments) and can therefore be considered typespecific strengths.

However, there are several deficits in WCS that were more frequently indicated as RQ and were less likely to act as arguments attracting new employees (Inability). For example, nurses who quit because of exhaustion and/ or a poor work-life balance were more likely to have worked at a public hospital.

\section{Private hospitals}

Nurses who left the former organisation because of low salary, too much non-nursing tasks, aggression and/or bad care quality were more likely to go to a private hospital. However, since care quality was also measured a strong push argument (Paradox), one may argue that private hospitals might be very heterogeneous regarding this aspect. Furthermore, nurses at private hospitals were more likely to come and go as a consequence of changing the place of residence.

What seems favourable to private hospitals is-moreover-that nurses were less likely to quit because of exhaustion, inconvenient work hours and low skill-use opportunity (Chance). Furthermore, work-life balance and professional identification were measured weak push arguments. But since these were also less likely to pull nurses towards private hospitals (Irrelevance), it may suggest that nurses at private hospitals are not overly seeking

$$
\left(O R_{\text {Push }} \geq 1 \rightarrow x_{\text {Criterion } \varphi}=O R_{\text {Push }}-1\right) \wedge\left(O R_{\text {Push }}<1 \rightarrow x_{\text {Criterion } \varphi}=\frac{-1}{O R_{\text {Push }}}+1\right)
$$

And the $y$ coordinate for criterion $\phi$ was defined as increased professional identification or enhanced workfollows:

life balance, in the first place.

$$
\left(O R_{\text {Pull }} \geq 1 \rightarrow y_{\text {Criterion } \varphi}=O R_{\text {Pull }}-1\right) \wedge\left(O R_{\text {Pull }}<1 \rightarrow y_{\text {Criterion } \varphi}=\frac{-1}{O R_{\text {Pull }}}+1\right)
$$

\section{Results}

Figure 2 shows the specific competitive strengthsand-weaknesses diagram for public hospitals, while Additional file 3 presents the diagrams for the other employer types. Table 3 holds the aggregated results.

\section{Private medical offices}

Nurses working at private medical offices were more likely to leave because they could not use their skills, had low advancement opportunities and did tasks that they considered to be non-nursing activities. They were also 
Push and Pull Factors: PuHs

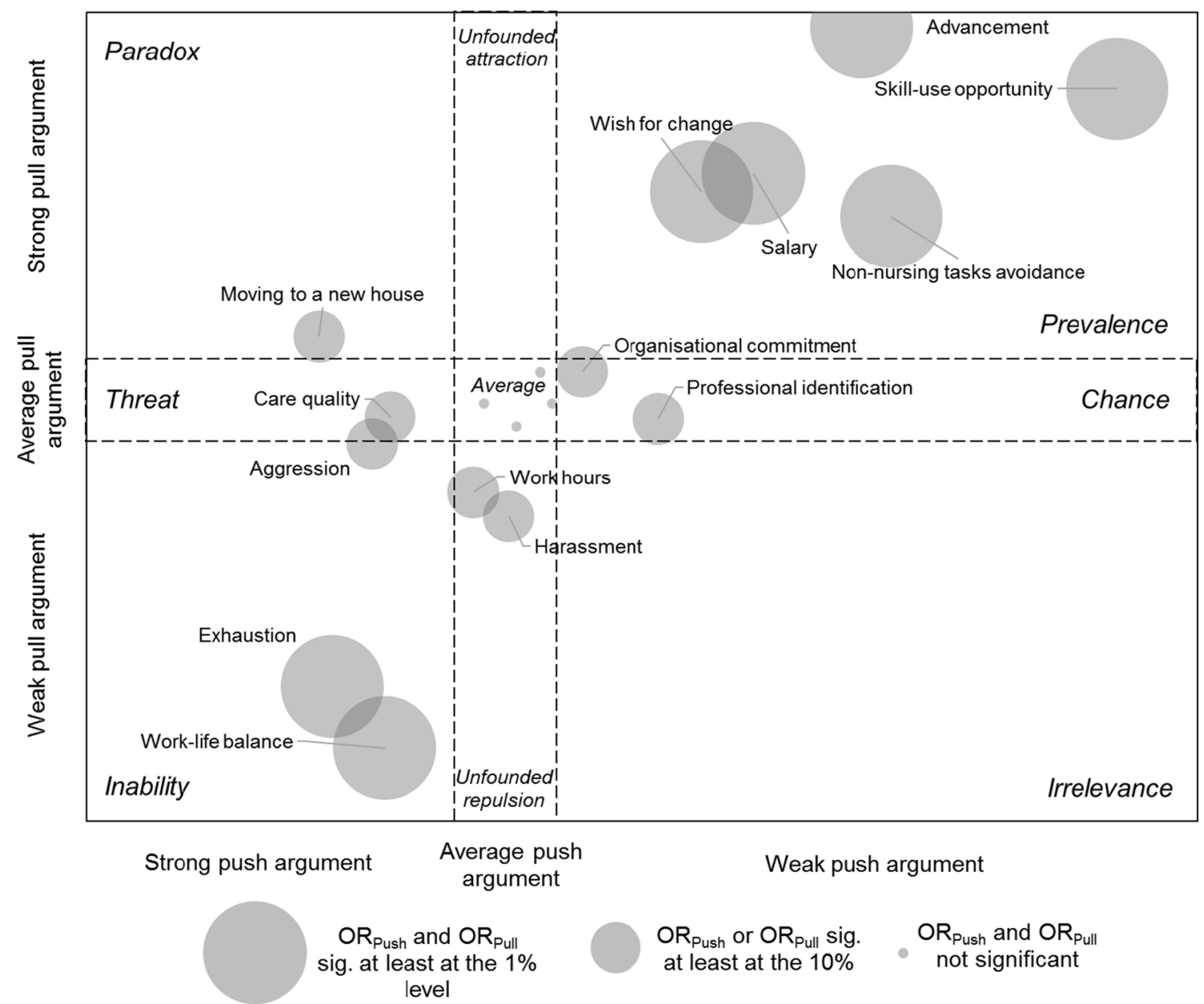

Fig. 2 Push-and-pull factors associated with working at public hospitals. Notes: coordinates based on transformed odds ratios of cluster-robust weighted bivariate logistic regressions determining the push-and-pull characteristics of each criterion

more likely to leave because of low self-actualisation and dissatisfaction with salary as well as lowered professional identification. Yet, these criteria were no weak pull arguments (Threat), what may indicate hidden disadvantages or heterogeneity within the employer type. What can be considered-however-as important competitive weakness (Inability) concerns the inability to adequately satisfy nurses' wish for change.

However, nurses at private medical offices were less likely to leave because of exhaustion and care quality, which can be considered as generally important reasons to leave a healthcare institution (see Additional file 4). Nevertheless, it could not be significantly measured that these also acted as strong pull factors (Chance). However, considered as a competitive strength-working as a strong pull argument while being a weak push argument (Prevalence)-are work hours. Finally, work-life balance is considered a strong pull argument, as well. That moving to a new house was located in the field Irrelevance field implies that nurses at private medical offices are either willing to accept longer distances between their home and their workplace or that they change their place of residence less frequently.

\section{SOMEDs}

In comparison to other nurses, it was more likely for SOMED employees to leave the organisations because of harsh WCS captured in several criteria. This was also reflected in the competitive disadvantage (Inability) that SOMEDs seemed to lack on providing interesting job offers and hence were losing nurses to more appealing workplaces. Moreover, that moving to a new house was measured a strong pull factors suggests that nurses are more likely to be urged to work for SOMEDs. 
Table 3 Summary of competitive turnover profiles

\begin{tabular}{|c|c|c|c|c|c|c|c|c|}
\hline & \multicolumn{3}{|c|}{ Employer strengths } & \multicolumn{3}{|c|}{ Employer weaknesses } & \multirow{2}{*}{$\begin{array}{l}\text { Paradox } \\
\text { (strong pull } \\
\text { argument; } \\
\text { strong push } \\
\text { argument) }\end{array}$} & \multirow{2}{*}{$\begin{array}{l}\text { Irrelevance } \\
\text { (weak pull } \\
\text { argument; } \\
\text { weak push } \\
\text { argument) }\end{array}$} \\
\hline & $\begin{array}{l}\text { Prevalence } \\
\text { (strong pull } \\
\text { argument; } \\
\text { weak push } \\
\text { argument) }\end{array}$ & $\begin{array}{l}\text { Unfounded } \\
\text { attraction } \\
\text { (strong pull } \\
\text { argument; } \\
\text { average push } \\
\text { argument) }\end{array}$ & $\begin{array}{l}\text { Chance } \\
\text { (average pull } \\
\text { argument; } \\
\text { weak push } \\
\text { argument) }\end{array}$ & $\begin{array}{l}\text { Inability } \\
\text { (strong push } \\
\text { argument; } \\
\text { weak pull } \\
\text { argument) }\end{array}$ & $\begin{array}{l}\text { Threat } \\
\text { (strong push } \\
\text { argument; } \\
\text { average pull } \\
\text { argument) }\end{array}$ & $\begin{array}{l}\text { Unfounded } \\
\text { repulsion } \\
\text { (average push } \\
\text { argument; } \\
\text { weak pull } \\
\text { argument) }\end{array}$ & & \\
\hline $\begin{array}{l}\text { Public hospi- } \\
\text { tals }\end{array}$ & $\begin{array}{l}\text { Advancement } \\
\text { Skill-use } \\
\text { opportunity } \\
\text { Wish for } \\
\text { change } \\
\text { Pay } \\
\text { Non-nursing } \\
\text { tasks avoid- } \\
\text { ance }\end{array}$ & & $\begin{array}{l}\text { Organisational } \\
\text { commit- } \\
\text { ment } \\
\text { Professional } \\
\text { identifica- } \\
\text { tion }\end{array}$ & $\begin{array}{l}\text { Exhaustion } \\
\text { Work-life bal- } \\
\text { ance }\end{array}$ & $\begin{array}{l}\text { Care quality } \\
\text { Aggression }\end{array}$ & $\begin{array}{l}\text { Work hours } \\
\text { Harassment }\end{array}$ & $\begin{array}{l}\text { Moving to a } \\
\text { new house }\end{array}$ & \\
\hline $\begin{array}{l}\text { Private hos- } \\
\text { pitals }\end{array}$ & $\begin{array}{l}\text { Aggression } \\
\text { Non-nursing } \\
\text { tasks avoid- } \\
\text { ance }\end{array}$ & Pay & $\begin{array}{l}\text { Exhaustion } \\
\text { Work hours } \\
\text { Skill-use } \\
\text { opportunity }\end{array}$ & & & $\begin{array}{l}\text { Self-actualisa- } \\
\text { tion }\end{array}$ & & $\begin{array}{l}\text { Professional } \\
\text { identification } \\
\text { Work-life bal- } \\
\text { ance }\end{array}$ \\
\hline $\begin{array}{l}\text { Private medi- } \\
\text { cal offices }\end{array}$ & Work hours & $\begin{array}{l}\text { Work-life bal- } \\
\text { ance }\end{array}$ & $\begin{array}{l}\text { Exhaustion } \\
\text { Care quality }\end{array}$ & $\begin{array}{l}\text { Wish for } \\
\text { change }\end{array}$ & $\begin{array}{l}\text { Skill-use } \\
\text { opportunity } \\
\text { Advancement } \\
\text { Pay } \\
\text { Self-actualisa- } \\
\quad \text { tion } \\
\text { Non-nursing } \\
\text { tasks avoid- } \\
\text { ance } \\
\text { Professional } \\
\text { identification }\end{array}$ & & & $\begin{array}{l}\text { Aggression } \\
\text { Moving to a new } \\
\text { house }\end{array}$ \\
\hline $\begin{array}{l}\text { Socio-medical } \\
\text { institutions } \\
\text { (SOMEDs) }\end{array}$ & & $\begin{array}{l}\text { Harassment } \\
\text { Moving to a } \\
\text { new house }\end{array}$ & & $\begin{array}{l}\text { Interesting job } \\
\text { offer } \\
\text { Advancement }\end{array}$ & $\begin{array}{l}\text { Team } \\
\text { Self-actualisa- } \\
\text { tion } \\
\text { Work hours } \\
\text { Skill-use } \\
\text { opportunity } \\
\text { Non-nursing } \\
\text { tasks avoid- } \\
\text { ance } \\
\text { Organisational } \\
\text { commit- } \\
\text { ment }\end{array}$ & $\begin{array}{l}\text { Wish for } \\
\text { change } \\
\text { Pay }\end{array}$ & $\begin{array}{l}\text { Exhaustion } \\
\text { Aggression } \\
\text { Care quality } \\
\text { Superiors }\end{array}$ & \\
\hline $\begin{array}{l}\text { Non-profit } \\
\text { organisa- } \\
\text { tions (NPOs) }\end{array}$ & $\begin{array}{l}\text { Wish for } \\
\text { change }\end{array}$ & Harassment & $\begin{array}{l}\text { Interesting job } \\
\text { offer } \\
\text { Self-actualisa- } \\
\text { tion }\end{array}$ & & & $\begin{array}{l}\text { Work hours } \\
\text { Skill-use } \\
\text { opportuni- } \\
\text { ties }\end{array}$ & & $\begin{array}{l}\text { Advancement } \\
\text { Pay } \\
\text { Care quality }\end{array}$ \\
\hline $\begin{array}{l}\text { Home-care } \\
\text { services }\end{array}$ & $\begin{array}{l}\text { Self-actualisa- } \\
\text { tion } \\
\text { Care quality }\end{array}$ & $\begin{array}{l}\text { Exhaustion } \\
\text { Team }\end{array}$ & $\begin{array}{l}\text { Wish for } \\
\text { change }\end{array}$ & & & & Work hours & \\
\hline
\end{tabular}

Looking at further strong pull factors of SOMED workplaces, we paradoxically observed that the factors like exhaustion, care quality and superiors-while strongly pushing nurses away from SOMEDs-also were more likely to attract nurses (Paradox). This may either suggest that there is a sub-segment of SOMED workplaces that offers good conditions regarding these aspects or that nurses have false expectations towards theses specific WCS at SOMEDs.

\section{NPOs}

NPO workplaces were more likely to attract nurses with a wish for change of work content while still working as nurses (Prevalence). Additionally, NPOs seem to prevail in providing interesting jobs, with much autonomy and participation (e.g. self-actualisation), although the criteria were yet located in the field of Chance. This implies that human resource management (HRM) at NPOs should stress these aspects more in their communication 
measurements to make them strong pull arguments. That personality and distinct motivational patterns could play a crucial role in attracting NPO nurses is supported by the irrelevance of factors that were of central interest in other employer profiles: salary, advancement and care quality.

\section{Home-care services}

In comparison to other nurses, nurses in home care services were not more likely to quit because of a specific reason, except because of inconvenient work hours. The fact that it was at the same time measured a strong pull factor (Paradox) is explainable by the ambivalent nature of the criterion (need variance). Like private medical offices, home care services offer shifts that clearly differ from hospitals (e.g. less night shifts needed).

Moreover, nurses who quit their former employers because of exhaustion, team-related aspects, care quality and lack of self-actualisation were more likely to choose home care services as their follow-up employers. The latter two criteria were, in addition, also measured weak push arguments making them strong competitive advantages (Prevalence) which seems even more favourable since these factors are generally rather common RQs (see Additional file 4).

\section{Conclusion}

\section{Practical implications}

In the rising competition for well-trained employees, nurses choose their follow-up employer deliberately according to criteria they ascribe to specific types of organisations. The turnover profiles presented in this article not only show that there is need for competitive agility but reveal, as well, where different types of employer should begin to improve and contrast, independently from their firm-specific branding or their business strategies. Depending on the position of workplace criteria in the specific competition-oriented diagram, employers may use the generic strategic HRM and employer branding recommendations suggested in Additional file 2. Criteria located in the Prevalence field are strong competitive advantages and can be communicated highly credibly to attract nursing workforce. Opposed to these, criteria in the Inability field are type-innate weaknesses which should be supervised carefully. Although HRM may never turn them into competitive advantages, these weaknesses should be enhanced to an acceptable level to reduce turnover. Criteria located in the Paradox field need further analysis since they underlie effects of either high workforce sensitivity, workforce heterogeneity or distorted employer perceptions on the labour market.
Criteria allocated in the Irrelevance field are comparatively less involved in both nurse turnover and attraction. Hence, in competitive comparison, these criteria do not ask for immediate treatment by the HRM. However, criteria which reach significance either in their competitive push or pull dimensions but not on both indicate either positive or negative branding potential in one dimension, which should be addressed appropriately.

As the results bring more transparency to the nurses' labour market and present the push-and-pull factors of major groups of health employers, this study may interest human resource management and employer branding professionals, support nurses in their career decisions and guide political and economic representatives of specific types of employers or nurses in Switzerland (i.e. professional associations and industry organisations) in their discussion of nurses' WCS.

Although healthcare systems and labour markets differ across countries, our findings may be relevant for future research and HR managers abroad. After all, the discussed theoretical effects of institutional characteristics such as size, activity field and goal system are less bound to the political and socio-economic context. Moreover, the basic typology of major nurse employers may be found worldwide (hospitals, doctor's offices, home care services and for-profit vs. non-profit offices). Furthermore, although correlations for specific variables involved in turnover decisions vary across countries and therefore hint at the importance of national contexts [80], similar outcomes and unidirectional effects for key predictors of turnover intention, such as job satisfaction, stress or burnout, are shown in literature reviews and cross-country studies of nurse turnover and working conditions such as RN4CAST or the NEXT study [52, 61, 80-82].

\section{Limitations and implications for future research}

Our research has some limitations. The surveyed sample may suffer self-selection bias and therefore lack representativeness because a sampling frame such as a registry of professional nurses was not available. Furthermore, while RQs were surveyed with each left employer, the questionnaire did not address the reasons why a certain employer was joined. This limitation was overcome using implicit pull factors as described earlier. Moreover, although the survey considered several RQs, the literature suggests further unassessed reasons for a voluntary turnover that could account for additional variance in career decisions. For example, nurses may be pulled out of the organisation by former peers and join them to another [6,83]. 
We introduced a method to map results based on inferential statistical analyses, which can be adapted to any competitive field and extended with any control variables. Furthermore, the approach offers high automation potential for career platforms such as LinkedIn, which have already implemented analytics for organisations to identify recruitment competitors based on employee turnover. Surveying push-and-pull factors may result in the automated creation of competitive employer profiles online.

Future research may examine employer changes qualitatively and evaluate individuals' expectations and experiences before and after the change. Moreover, as this study is limited to previous and follow-up employers only, future studies may explore the career paths of nurses across various healthcare employers holistically to shape employer branding with a better understanding of what nurses seek in their long-term careers.

The analysis revealed imperfect transparency in the applicants' market regarding WCS with specific employers, which can be both useful and unfortunate for HRM. Moreover, the results indicate that different personality types attracted by specific employer types relativises the importance of certain WCS and their involvement in career decisions, which needs further research.

The nurse data were collected as early as 2014; hence, timely representativeness may be limited. However, because of the large sample size and data covering careers ranging back decades, our findings may rely on more structural and innate characteristics in the health sector and labour market while having relativised short-term changes and extraordinary events to insignificancy. Underlying theories have been proven valid over time and career decisions are affected by longterm experiences [84]. Finally, studies and literature reviews from different decades have shown the persistence of the main challenges and key factors associated with nurse staffing, turnover and working conditions, such as stress, burnout and organisational commitment as key predictors of turnover intention $[81,85,86]$.

Finally, the competitive positioning of nurses' employers in other countries may be assessed in future studies, providing more information about the robustness of the competitive push-and-pull profiles of employers across different healthcare systems, political and economic environments, hospital and professional standards and work regulations.

\section{Abbreviations}

AF: Additional file; HRM: Human resource management; NPOs: Non-profit organisations; PCA: Principal component analysis; RQ(s): Reason(s) to quit; SOMEDs: Socio-medical institutions; WCS: Working conditions.

\section{Supplementary Information}

The online version contains supplementary material available at https://doi. org/10.1186/s12960-021-00586-z.

Additional file 1: Movement sample composition

Additional file 2: Profiling nurse turnover: interpreting criteria allocation and deriving strategic reactions

Additional file 3: Strengths-and-weaknesses diagrams for private hospitals, private medical offices, SOMEDs, NPOs, and home care services

Additional file 4: Relevance of reasons to quit involved in cross-typical turnover

\section{Acknowledgements}

We thank the nurses at work team members: Véronique Addor [University of Applied Sciences and Arts Western Switzerland, (HES-SO), Principal Investigator], Jacques-Antoine Gauthier (University of Lausanne), René Schwendimann (University of Basel), Adeline Paignon [University of Applied Sciences and Arts Western Switzerland (HES-SO)], Dalit Jäckel (University of Basel) and Boris Wernli [Swiss Centre of Expertise in the Social Sciences (FORS)].

\section{Authors' contributions}

RA performed the statistical analyses, interpreted the data and wrote the first draft of the manuscript. VA was the Principal Investigator of the nurses at work study, responsible for the study design, the questionnaire development and the data collection; she contributed to the manuscript. All authors read and approved the final manuscript.

\section{Funding}

The nurses at work study was supported by the Swiss National Science Foundation Swiss National Science Foundation Grant \#105318_147159, the Swiss Health Observatory Grant \#150010772, the State Secretariat for Education, Research and Innovation Grant \#88.2013.0042, the Federal Office of Public Health grant \#1014-50109 and the Haute école spécialisée de Suisse occidentale (HES-SO).

\section{Availability of data and materials}

The nurses at work database was made available by the authors upon submission of a research protocol.

\section{Declarations}

\section{Ethics approval and consent to participate}

Since an online survey concerning nurses' careers does not constitute biomedical research (Switzerland's Law on Research on Human Beings (L 810.30, art. 118)), this sub-study required no approval by the Swiss Ethics Commission. However, the nurses at work study requested and obtained a favourable presidential opinion from the Swiss Ethics Committee on research involving humans (Protocol 119/14 of April 16, 2014).

\section{Consent for publication}

Not applicable.

\section{Competing interests}

The authors declare that they have no competing interests.

\section{Author details}

${ }^{1}$ University of Fribourg (CH), Bd de Pérolles 90, 1700 Freiburg, Switzerland.

${ }^{2}$ University of Applied Sciences and Arts Western Switzerland (HES-SO),

Genève, Switzerland.

Received: 14 November 2020 Accepted: 25 February 2021

Published online: 06 April 2021 


\section{References}

1. Fox RL, Abrahamson K. A critical examination of the U.S. nursing shortage: contributing factors, public policy implications. Nurs Forum 2009;44(4):235-44.

2. Marć M, Bartosiewicz A, Burzyńska J, Chmiel Z, Januszewicz P. A nursing shortage - a prospect of global and local policies. Int Nurs Rev. 2018. https://doi.org/10.1111/inr.12473.

3. Hardegger, A. Nichts geht ohne die Care-Arbeit in der Corona-Krise. 2020. https://www.nzz.ch/schweiz/corona-und-care-pflegerinnen-am-limit-ld. 1546042? reduced=true. Accessed 1 Nov 2020

4. WHO. Year of the nurse and the midwife 2020. 2020. https://www.who.int/ campaigns/year-of-the-nurse-and-the-midwife-2020. Accessed 1 Nov 2020.

5. Addor V, Schwendimann R, Gauthier J-A, Wernli B, Jäckel D, Paignon A. «nurses at work» - Studie zu den Laufbahnen im Pflegeberuf über die letzten 40 Jahre in der Schweiz (Obsan Bulletin 8/2016). Neuchâtel: Schweizerisches Gesundheitsobservatorium; 2016.

6. Gilmartin MJ. Thirty years of nursing turnover research: looking back to move forward. Med Care Res Rev. 2013;70(1):3-28.

7. Holtom BC, Mitchell TR, Lee TW, Eberly MB. 5 turnover and retention research: a glance at the past, a closer review of the present, and a venture into the future. Acad Manag Ann. 2008;2(1):231-74.

8. Aeschbacher R, Addor V. Institutional effects on nurses' working conditions: a multi-group comparison of public and private non-profit and for-profit healthcare employers in Switzerland. Hum Resour Health. 2018;16(1):58

9. Blau PM. A formal theory of differentiation in organizations. Am Sociol Rev. 1970;35(2):201-18.

10. Astley WG. Organizational size and bureaucratic structure. Organ Stud 1985:6(3):201-28.

11. Pugh D, Hickson D, Hinings C. An empirical taxonomy of structures of work organizations. Adm Sci Q. 1969;14(1):115-26.

12. Bauer TK. High performance workplace practices and job satisfaction: evidence from Europe. IZA Discussion Paper No. 1265. 2004. https://ssrn. com/abstract=582304. Accessed 1 Nov 2020.

13. Appelbaum E, Berg P. High-performance work systems and labor market structures. In: Berg I, Kalleberg AL, editors. Sourcebook of labor markets. Boston: Springer; 2001. p. 271-93.

14. Winter-Ebmer R, Zweimüller J. Firm-size wage differentials in Switzerland: evidence from job-changers. Am Econ Rev. 1999;89(2):89-93.

15. Kalleberg A, Van Buren M. Is bigger better? Explaining the relationship between organization size and job rewards. Am Sociol Rev. 1996:61(1):47-66.

16. Idson TL. Establishment size, job satisfaction and the structure of work. Appl Econ. 1990;22(8):1007-18.

17. Idson T. Employer size and labor turnover. Discussion Paper. Columbia University, Department of Economics. 1993. https://academiccommons. columbia.edu/doi/10.7916/D8K36247/download. Accessed 1 Nov 2020

18. Griliches Z. Notes on the role of education in production functions and growth accounting. In: Hansen WL, editor. Education, income, and human capital. Cambridge: NBER; 1970. p. 71-127.

19. Barron J, Black D, Loewenstein M. Employer size: the implications for search, training, capital investment, starting wages, and wage growth. J Law Econ. 1987:5(1):76-89.

20. Bulow JI, Summers LH. A theory of dual labor markets with application to industrial policy, discrimination, and Keynesian unemployment. J Labor Econ. 1986;4(3, Part 1):376-414.

21. Oi W. The fixed employment costs of specialized labor. In: Tripplett JE, editor. The measurement of labor cost. Chicago: University of Chicago Press; 1983. p. 63-122.

22. Deci EL. The relation of interest to the motivation of behavior: a selfdetermination theory perspective. In: Renninger KA, Hidi S, Krapp A editors. The role of interest in learning and development. New York: Psychology Press; 1992. p. 43-70.

23. Hackman JR, Oldham G. Work redesign. Boston, MA: Addison-Wesley; 1980

24. Jordalen G, Lemyre PN, Durand-Bush N. Exhaustion experiences in junior athletes: the importance of motivation and self-control competencies. Front Psychol. 2016;7:1867.

25. Downie M, Mageau GA, Koestner R. What makes for a pleasant social interaction? Motivational dynamics of interpersonal relations. J Soc Psychol. 2008;148(5):523-34
26. Nezlek JB, Richardson DS, Green LR, Schatten-Jones EC. Psychological well-being and day-to-day social interaction among older adults. Pers Relat. 2002:9(1):57-71.

27. Braun B, Klinke S, Müller R, Rosenbrock R. Einfluss der DRGs auf Arbeitsbedingungen und Versorgungsqualität von Pflegekräften im Krankenhaus: Ergebnisse einer bundesweiten schriftlichen Befragung repräsentativer Stichproben von Pflegekräften an Akutkrankenhäusern in den Jahren 2003, 2006 und 2008. 2011. http://nbn-resolving.de/urn:nbn: de:0168-ssoar-375444. Accessed 27 Jan 2021.

28. Aiken LH, Clarke SP, Sloane DM, Lake ET, Cheney T. Effects of hospital care environment on patient mortality and nurse outcomes. J Nurs Adm. 2008;38(5):223-9.

29. Weisbrod BA. Toward a theory of the voluntary non-profit sector in a three sector economy. In: Phelps E, editor. Altruism, morality and economic theory. New York: Russell Sage; 1975. p. 171-96.

30. Chen CA. Explaining the difference of work attitudes between public and nonprofit managers: the views of rule constraints and motivation styles. Am Rev Public Adm. 2012:42(4):437-60.

31. Judge TA, Bono JE. Relationship of core self-evaluations traits—selfesteem, generalized self-efficacy, locus of control, and emotional stability — with job satisfaction and job performance: a meta-analysis. J Appl Psychol. 2001;86(1):80-92.

32. Aeschbacher R, Gmür M. Do non-profit organisations offer better places to work? A longitudinal analysis of cross-sectoral staff mobility. Die Unternehmung. 2019;73(2):109-21.

33. Perry JL. Bringing society in: toward a theory of public-service motivation. J Public Adm Res Theory. 2000;10(2):471-88.

34. McHugh MD, Kutney-Lee A, Cimiotti JP, Sloane DM, Aiken LH. Nurses' widespread job dissatisfaction, burnout, and frustration with health benefits signal problems for patient care. Health Aff. 2011;30(2):202-10.

35. Hegney D, Plank A, Parker V. Extrinsic and intrinsic work values: their impact on job satisfaction in nursing. J Nurs Manag. 2006;14(4):271-81.

36. Stordeur S, D'hoore W, van der Heijden B, Dibisceglie M, Laine $M$, van der Schoot E. Leadership, job satisfaction and nurses' commitment. In: Hasselhorn H-M, Tackenberg P, Müller BH, editors. Working conditions and intent to leave the profession among nursing staff in Europe. Stockholm: National Institute for Working Life; 2003. p. 28-45.

37. Cocco E, Gatti M, de Mendonça Lima CA, Camus V. A comparative study of stress and burnout among staff caregivers in nursing homes and acute geriatric wards. Int J Geriatr Psychiatry. 2003;18(1):78-85.

38. van der Schoot E, Ogińska H, Estryn-Behar M. Burnout in the nursing profession in Europe. In: Hasselhorn H-M, Tackenberg P, Müller BH, editors. Working conditions and intent to leave the profession among nursing staff in Europe. Stockholm: National Institute for Working Life; 2003. p. $53-7$

39. Hasson H, Arnetz JE. Nursing staff competence, work strain, stress and satisfaction in elderly care: a comparison of home-based care and nursing homes. J Clin Nurs. 2008;17(4):468-81.

40. Chung MC, Harding C. Investigating burnout and psychological wellbeing of staff working with people with intellectual disabilities and challenging behaviour: the role of personality. J Appl Res Intellect Disabil. 2009;22(6):549-60.

41. Pokorski J, van der Schoot E, Wickström G, Pokorska J, Hasselhorn H-M. Meaning of work in the European nursing profession. In: Hasselhorn $\mathrm{H}-\mathrm{M}$, Tackenberg $\mathrm{P}$, Müller $\mathrm{BH}$, editors. Working conditions and intent to leave the profession among nursing staff in Europe. National Institute for Working Life: Stockholm; 2003. p. 58-63.

42. Stacey $\mathrm{CL}$. Finding dignity in dirty work: the constraints and rewards of low-wage home care labour. Sociol Health IIIn. 2005;27(6):831-54.

43. Brunetto $Y$, Farr-Wharton $R$, Shacklock K. The impact of supervisor-subordinate relationships on morale: implications for public and private sector nurses' commitment. Hum Resour Manag J. 2010;20(2):206-25.

44. Rojas D, Seghieri C, Nuti S. Organizational climate: comparing private and public hospitals within professional roles. Suma De Negocios. 2014;5(11):10-4.

45. Jeong JE, Jeong LG. A study on choice motives and job satisfaction about nurses who changed jobs to public hospitals. Korean J Occup Health Nurs. 2017;26(1):55-64

46. Hansen N, Sverke M, Näswall K. Predicting nurse burnout from demands and resources in three acute care hospitals under different forms of 
ownership: a cross-sectional questionnaire survey. Int J Nurs Stud 2009;46(1):95-106.

47. Ben-Ner A, Ren T, Paulson DF. A sectoral comparison of wage levels and wage inequality in human services industries. Nonprofit Volunt Sect Q. 2010;40(4):608-33.

48. Bos A, Boselie P, Trappenburg M. Financial performance, employee well-being, and client well-being in for-profit and not-for-profit nursing homes: a systematic review. Health Care Manag Rev. 2017;42(4):352-68.

49. Benz M. Not for the profit, but for the satisfaction? - evidence on worker well-being in non-profit firms. Kyklos. 2005;58(2):155-76.

50. Shin S, Park JH, Bae SH. Nurse staffing and nurse outcomes: a systematic review and meta-analysis. Nurs Outlook. 2018;66(3):273282.

51. Ball JE, Bruyneel L, Aiken LH, Sermeus W, Sloane DM, Rafferty AM, Lindqvist R, Tishelman C, Griffiths P, RN4Cast Consortium. Post-operative mortality, missed care and nurse staffing in nine countries: a cross-sectional study. Int J Nurs Stud. 2018;78:10-5.

52. Aiken LH, Sloane DM, Bruyneel L, Van den Heede K, Griffiths P, Busse R, Diomidous M, Kinnunen JK, Kózka M, Lesaffre E, McHugh M, MorenoCasbas MT, Rafferty AM, Schwendimann R, Scott PA. Nurse staffing and education and hospital mortality in nine European countries: a retrospective observational study. The Lancet. 2014;383(9931):1824-30.

53. Aiken LH, Sermeus W, Van den Heede K, Sloane DM, Busse R, McKee M, Bruyneel L, Rafferty AM, Griffiths P, Moreno-Casbas MT, Tishelman C, Scott A, Brzostek T, Kinnunen J, Schwendimann R, Heinen M, Zikos D, Strømseng Sjetne I, Smith HL, Kutney-Lee A. Patient safety, satisfaction, and quality of hospital care: cross sectional surveys of nurses and patients in 12 countries in Europe and the United States. BMJ. 2012. https://doi. org/10.1136/bmj.e1717.

54. Schubert M, Clarke SP, Aiken LH, De Geest S. Associations between rationing of nursing care and inpatient mortality in Swiss hospitals. Int J Qual Health Care. 2012;24(3):230-8.

55. Gillet N, Fouquereau E, Coillot H, Cougot B, Moret L, Dupont S, Colombat P. The effects of work factors on nurses' job satisfaction, quality of care and turnover intentions in oncology. J Adv Nurs. 2018;74(5):1208-19.

56. Al Sabei SD, Labrague $L$, Miner Ross A, Karkada S, Albashayreh A, Al Masroori F, Al HN. Nursing work environment, turnover intention, job burnout, and quality of care: the moderating role of job satisfaction. $J$ Nurs Scholarsh. 2020;52(1):95-104.

57. Han RM, Carter P, Champion JD. Relationships among factors affecting advanced practice registered nurses' job satisfaction and intent to leave: a systematic review. J Am Assoc Nurse Pract. 2018;30(2):101-13.

58. Beecroft PC, Dorey F, Wenten M. Turnover intention in new graduate nurses: a multivariate analysis. J Adv Nurs. 2008;62(1):41-52.

59. Khan $N$, Jackson $D$, Stayt $L$, Walthall $H$. Factors influencing nurses' intentions to leave adult critical care settings. Nurs Crit Care. 2019;24(1):24-32.

60. Kelly LA, Gee PM, Butler RJ. Impact of nurse burnout on organizational and position turnover. Nurs Outlook. 2020;69:96-102.

61. McDermid F, Mannix J, Peters K. Factors contributing to high turnover rates of emergency nurses: a review of the literature. Aust Crit Care. 2019;33:390-6.

62. Dilig-Ruiz A, MacDonald I, Varin MD, Vandyk A, Graham ID, Squires JE. Job satisfaction among critical care nurses: a systematic review. Int J Nurs Stud. 2018:88:123-34.

63. Nei D, Snyder LA, Litwiller BJ. Promoting retention of nurses: a metaanalytic examination of causes of nurse turnover. Health Care Manag Rev. 2015;40(3):237-53.

64. Havaei F, MacPhee M, Dahinten VS. RN s and LPN s: emotional exhaustion and intention to leave. J Nurs Manag. 2016;24(3):393-9.

65. Hung MS, Lam SK. Antecedents and contextual factors affecting occupational turnover among registered nurses in public hospitals in Hong Kong: a qualitative descriptive study. Int J Environ Res Public Health. 2020;17(11):3834

66. Sasso L, Bagnasco A, Catania G, Zanini M, Aleo G, Watson R, RN4CAST@ IT Working Group. Push and pull factors of nurses' intention to leave. J Nurs Manag. 2019;27(5):946-54.

67. Göktepe N, Yalçın B, Türkmen E, Dirican Ü, Aydın M. The relationship between nurses' work-related variables, colleague solidarity and job motivation. J Nurs Manag. 2020;28(3):514-21.
68. Brewer CS, Kovner CT, Greene W, Tukov-Shuser M, Djukic M. Predictors of actual turnover in a national sample of newly licensed registered nurses employed in hospitals. J Adv Nurs. 2012;68(3):521-38.

69. Majeed N, Jamshed S. Nursing turnover intentions: the role of leader emotional intelligence and team culture. J Nurs Manag. 2020;00:1-12.

70. Hølge-Hazelton B, Berthelsen CB. Leading unique cultures in departments with low turnover of nurses. A positive deviance approach study. J Nurs Manag. 2020;28(6):1207-14.

71. Hølge-Hazelton B, Berthelsen CB. Why do nurses stay? A positive deviance study of nurse turnover. Eur J Public Health. 2020;30(Supplement_5) ckaa166.629.

72. Sellgren SF, Kajermo KN, Ekvall G, Tomson G. Nursing staff turnover at a Swedish university hospital: an exploratory study. J Clin Nurs. 2009;18(22):3181-9.

73. Laine M, Pentti J, Wickström G. Intent to leave nursing in Finland. In: Hasselhorn H-M, Tackenberg P, Müller BH, editors. Working conditions and intent to leave the profession among nursing staff in Europe. Stockholm: National Institute for Working Life; 2003. p. 146-56.

74. Estryn-Behar M, Le Nézet O, Affre A, Arbieu P, Bedel M, Bonnet N, Derrienic F, Fayet C, Gadier G, Loriol M, Salbreu R, Ben-Brick E, Caillard J-F. Intent to leave nursing in France. In: Hasselhorn HM, Tackenberg P, Müller $\mathrm{BH}$, editors. Working conditions and intent to leave the profession among nursing staff in Europe. Stockholm: National Institute for Working Life; 2003. p. 157-70.

75. Gould D, Fontenla M, Anderson S, Conway L, Hinds K. Intention to leave nursing in the United Kingdom. In: Hasselhorn H-M, Tackenberg P, Müller $\mathrm{BH}$, editors. Working conditions and intent to leave the profession among nursing staff in Europe. Stockholm: National Institute for Working Life; 2003. p. 171-81.

76. Josephson M, Lindberg P, Voss M, Alfredsson L, Vingård E. The same factors influence job turnover and long spells of sick leave-a 3-year follow-up of Swedish nurses. Eur J Public Health. 2008;18(4):380-5.

77. Van Breukelen W, Van der Vlist R, Steensma H. Voluntary employee turnover: combining variables from the 'traditional' turnover literature with the theory of planned behavior. J Organ Behav. 2004;25(7):893-914.

78. Atchley R. Frontline workers in long-term care: recruitment, retention, and turnover issues in an era of rapid growth. 1996. Scripps Gerontology Center Publications. https://sc.lib.miamioh.edu/bitstream/handle/2374. MIA/104/fulltext.pdf. Accessed 1 Nov 2020.

79. Hiscott RD. Career paths of nursing professionals: a study of employment mobility. Montreal: McGill-Queen's Press-MQUP; 1998.

80. Heinen MM, van Achterberg T, Schwendimann R, Zander B, Matthews A, Kózka M, Ensio A, Strømseng Sjetneg I, Casbas M, Ball J, Schoonhoven L. Nurses' intention to leave their profession: a cross sectional observational study in 10 European countries. Int J Nurs Stud. 2013;50(2):174-84.

81. Lu H, While AE, Barriball KL. Job satisfaction among nurses: a literature review. Int J Nurs Stud. 2005;42(2):211-27.

82. Tackenberg P, Müller B, Next-Study group. Working conditions and intent to leave the profession among nursing staff in Europe. 2003. https://www.researchgate.net/profile/Hans_Hasselhorn/publication/ 242742550_Work_Conditions_and_Intent_to_Leave_the_Profession Among_Nursing_Staff_in_Europe/links/Of317531a40e28943c000000.pdf. Accessed 27 Jan 2021.

83. Soltis SM, Agneessens F, Sasovova Z, Labianca G. A social network perspective on turnover intentions: the role of distributive justice and social support. Hum Resour Manag. 2013;52(4):561-84.

84. Larsen PD, McGill JS, Palmer SJ. Factors influencing career decisions: perspectives of nursing students in three types of programs. J Nurs Educ. 2003;42(4):168-73.

85. Lu H, Zhao Y, While A. Job satisfaction among hospital nurses: a literature review. Int J Nurs Stud. 2019;94:21-31.

86. Blegen MA. Nurses'job satisfaction: a meta-analysis of related variables. Nurs Res. 1993;42(1):36-41.

\section{Publisher's Note}

Springer Nature remains neutral with regard to jurisdictional claims in published maps and institutional affiliations. 